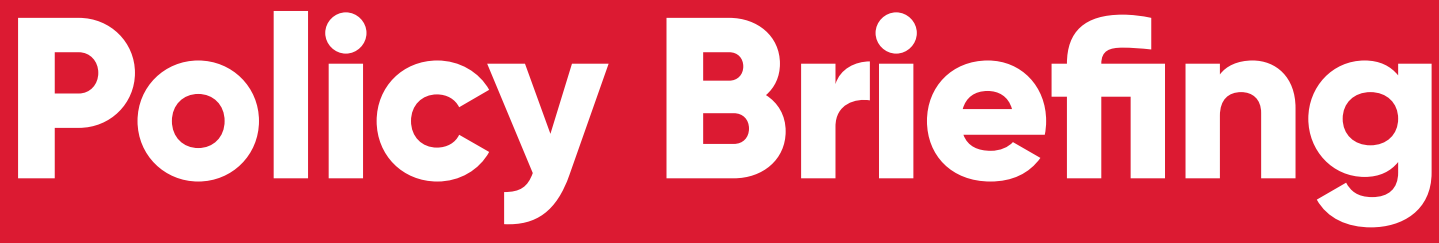

\title{
Shaping Social Change with Music in Maputo,
} Mozambique

In Mozambique, development programmes have traditionally drawn on music as a means to promote social transformation by educating citizens on key social development issues. Shifting the focus from music as a teaching medium to music as a rich source of information can provide vital insights into public opinion and political ideas, and significantly impact the development of citizen engagement projects. Maximum gains for development and civil society agencies can be achieved by mainstreaming gender into mutual learning activities between singers, audiences, and academics.

\section{Key messages}

- In dominant approaches to development programmes the use of music for social transformation is often premised on the idea of music as an educational tool for citizens, functioning merely as a medium through which organisations can make pre-determined complex messages more accessible.

- New analysis of protest songs composed in the past two decades in Mozambique is highlighting the ways in which music can also be interpreted to provide alternative understandings of demands for public accountability.

- Through this broader approach to music, development and civil society agencies can conceive and implement projects that foster meaningful collaborations between singers, audiences and academics, and promote empowering engagements with citizens.

30

The

composition, performance, and shared experience of protest songs constitutes political action.
Kátia Taela, Euclides Gonçalves, Catija Maivasse and Anésio Manhiça 


\section{An alternative approach to the arts for social transformation}

In the past two decades, national and international development and civil society agencies have increased the use of song to build citizenship and to support public demands for public accountability and political participation. This has entailed the commissioning of albums on citizenship, the integration of music and other cultural expressions in debates about state-society relations, and the creation of spaces for public dialogue where musicians perform and discuss governance issues with audiences. However, collaborations with musicians are limited to using music as a vehicle to pass on already conceived messages.

New research shows that issues raised in Mozambican protest songs are yet to influence the definition of thematic areas of work of the organisations that seek music to support social and political action. Rather than simply using music to pass on preconceived messages, organisations and institutions working on the promotion of citizen engagement should consider music as a source of knowledge to gauge 'the pulse of the street'. For instance, inadequate urban transport has been a key topic in protest songs over the past 20 years, yet very few organisations work in this area.

When examined as a collective body of work, the messages and performances of protest songs can provide understandings of demands for public accountability and political action which expand the repertoire of the limited occasions when citizens' views and action are expressed in public protests.

\section{Citizenship through music}

In Mozambique there are limited formal spaces for citizens to express their political views. In the past two decades, civil society organisations such as Grupo Moçambicano da Dívida (Mozambican Debt Group), Fórum Mulher (Women's Forum), and Fundação

\section{To tackle the under- and misrepresentation of women in political song, female songwriters and singers must be proactively invited to participate.}

MASC (Civil Society Support Mechanism Foundation) have been promoting citizen engagement in service delivery and policy dialogue. Drawing on the power of the protest song, organisations such as these are increasingly including musicians as part of citizen awareness campaigns in a variety of edutainment initiatives. Examples include Fundação MASC's Governance Festival and Parlamento Juvenil's The Citizen's Moon which incorporate arts and culture to contribute to build citizenship and foster citizen empowerment and political action. However, they rarely take into account the ways in which citizens communicate their political views through expressions of popular culture such as music.

Music remains an important outlet for people to communicate their political opinions and ideas. The composition, performance, and shared experience of protest songs constitutes political action. Edutainment initiatives could be enriched if programmers think beyond instrumental approaches to music and consider listening to and learning from messages already contained in protest songs and how both the musicians and audiences engage with them.

\section{The Maputo protest song}

Protest songs are concerned with public affairs, particularly public policy and how it affects citizens' social, political, and economic life, and the relationship between citizens and the state. 
The research that provided the basis for this briefing investigated whether notions of empowerment and accountability are present in popular music; what existing notions reveal about citizen-state relations in general and about citizen-led social and political action in particular; and how popular music has been used to support citizen mobilisation.

The analysis focused on protest songs popular in Maputo city and province in the past two decades. It revealed that Mozambicans in Maputo have been quick to create and adopt new vocabularies aligned with the language of rights of the democratic dispensation and use them to express demands for accountability. A large majority of protest songs of the past two decades has been composed by young men, mostly hiphop artists, who consider themselves to be expressing 'the voices of the people'.

\section{Key issues raised in the protest song in Maputo}

Analysis of political songs in Maputo city and province from 1998 to 2018, revealed eight recurrent topics: the economic situation, corruption, political-military crisis/peace, protests/popular action, police, public transport, progress, and donors.

The theme economic situation is a category composed of sentiments related to the general economic situation of the country, in particular the high cost of living, hunger, and unemployment. The songs describe a highly unequal society where people on low incomes must learn how to find dignity and happiness at times when economic hardships are perceived as a result of the ruling elite's extravagance and growing appetite for public resources.

The recent (2013-20) political-military conflict between the armed wing of Mozambique's main opposition party, Renamo, and government troops was a theme across songs calling for peace, especially as the armed conflict imposed severe travel restrictions, displaced people, and constrained service provision, bringing back memories of the civil war that ended in 1992. Politicians, and President Guebuza more specifically, were largely blamed for allowing the resurgence of the armed conflict in the country, for he was in power at the time and therefore in position to respond to and accommodate the demands of his political opposition.

Corruption features as both the cause and consequence of the economic situation. It is generally associated with public servants who are described as overindulging themselves on the privileges of public office. 'Big corruption' of opulent senior public officials is

\section{Figure 1 Recurrent topics and percentage of songs referring to them}

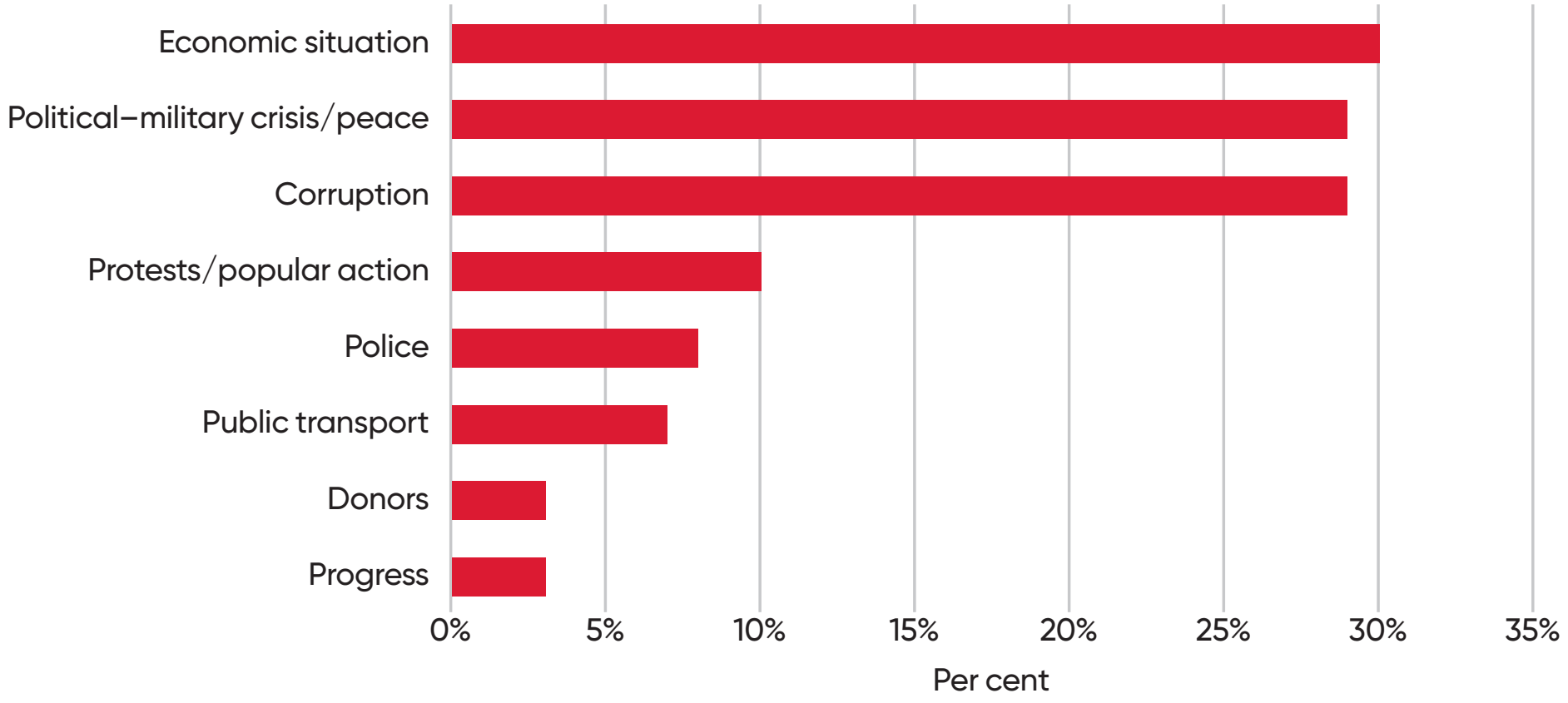


contrasted with 'small corruption' of frontline workers whose low salaries and poor working conditions often affect the quality of service delivery. The widespread corruption reaches the justice system and the police and the courts are seen as institutions that 'arrest chicken thieves, and [let] hashish dealers pay bail', as articulated in the song 'País da marrabenta' by Gpro-Fam.

In response to economic hardships, corruption and an imminent second civil war, some musicians composed songs calling for popular action. The songs suggest that citizens should not only see themselves as victims but also realise that they have the power to vote public officials into office and remove them if they do not perform well. In extreme situations, there are also different forms of public protest available to citizens who are the ultimate victims of poor governance.

The phrase 'we are investigating', used in police media briefings to respond to questions regarding new and old criminal cases has come to epitomise in popular culture the inefficiency of Mozambican police. In the protest song, police inefficiency is attributed to limited human and material resources but also to rampant corruption within the police force, which at times makes it difficult to distinguish between police and criminals. The picture that emerges from the songs is one in which citizens are ambivalent towards a police force from which they expect protection but more often than not face harassment and repression, especially during public protests.

The public transport system is probably the most shared collective experience of poor public services in Maputo. Ta Basilly's song 'My love' describes the shared challenge of high transport fares, unpredictable routes, and insufficient and overloaded buses. 'My loves' are medium-sized trucks (of one to four tonnes) used for public transportation and introduced by unregistered operators in response to the public transport crisis, especially in the outskirts of Maputo city. The name 'my love' describes the erosion of

\section{It is important to also capture audiences' viewpoints to ensure that broader citizens' perspectives are taken into consideration.}

intimacy barriers that results from the fact that standing passengers have to hold on to one another to avoid falling from the overloaded moving vehicle. Initially the government attempted to prohibit the circulation of 'my loves' due to security and health concerns but ultimately not only has it allowed these unregistered operators to circulate but also introduced its own version of seated 'my loves'.

The idea of progress and economic development emerges in the songs and contrasts with consecutive unfulfilled promises of a 'better future' made by the ruling elite. Songs that celebrate Mozambique's progress and economic development often build on nationalistic rhetoric or official reports of economic growth in contrast to protest songs where nationalistic rhetoric is used to speak ironically of the conditions of deprivation in which the majority of the population lives.

Since the structural adjustment programmes of the mid-1980s, donors have been a key feature of the Mozambican political and economic scenes. Following the 1992 peace agreement, donors' approaches moved from the initial focus on post-war reconstruction projects to the building of multiple-party democratic institutions and social and economic development projects. In the protest songs, donors are criticised for 'supporting' corrupt and unaccountable governance as the mixing of aid and trade become more apparent to citizens.

\section{Gender divides}

The composition and performance of protest songs in Maputo is largely dominated by young men. Gender relations feature in their songs yet male singers often present a 
misogynist view of women, portraying them as ambitious people who sell their bodies in exchange for money, school grades, jobs, or promotions. These negative references to women's bodies are made in relation to the deteriorating socioeconomic situation and the inadequate service delivery and corruption associated with it. Also present, but less prominent, are representations of women as mothers and heads of singleparent households, usually in reference to the artists' own mothers. Songs that challenge unequal gender relations are generally commissioned to female singers by organisations working on women's rights as part of awareness raising and advocacy campaigns.

\section{Singing as empowerment and challenging unaccountability}

To musicians, the political song serves primarily as a platform to acknowledge and put into perspective their political and economic position. The lyrics emerge as a vehicle to amplify subdued voices in a context where critique of those in government can result in reprisals.

Framing their work as 'intervention music', some musicians and music producers consider themselves to be expressing the 'voices of the people' and see writing and performing protest songs as a form of activism. This view gives expression to a dimension of empowerment that recognises the potential of individuals to shape their lives and world and engenders the possibility of collective action. However, some musicians believe that they should do more: integrate with social movements, engage in and mobilise others for civic action, showing by example that everybody has a part to play in solving societal problems, thus underlining the importance of collective action.

The song lyrics analysed demand explanations about the social, economic, and political problems Mozambicans in Maputo face. They ask why the government is not addressing specific issues, such as the loss of lives due to the military conflict between Renamo and Frelimo or the problem of public transport. The lyrics also question Frelimo's claims to being the sole legitimate ruler of Mozambique given its status as a colonial liberation movement. Mistrust and scepticism over Frelimo's willingness to protect the interests of Mozambicans overall has resulted in expressions of a desire for political power alternation. In the songs, invocations of late president Samora Machel draw a picture of an idyllic political past. While most of the commentary in the songs is addressed to Frelimo, the only party who has governed the country since its independence in 1975, members of parliament from all political parties also feature in songs, as they are perceived to have alienated themselves from their constituencies.

Musicians, producers, promoters, and audiences highlighted that protest song contributes to raising awareness about socioeconomic and political problems, awakens people to governance issues, and therefore, in their view, serves an educational purpose. However, there is also a desire to move beyond awareness raising and challenge what some perceive as passive behaviour in the face of exploitation and injustices. Lyrics call for both individual and collective action rooted in a belief that people-led political action is the pathway for social change. Individual action includes engaging with politics, voting wisely, and denouncing injustices, while collective action is mainly enunciated in terms of unity and voice in the street, through non-violent protests.

\section{6}

There is a desire to move beyond awareness raising and challenge what some perceive as passive behaviour in the face of exploitation and injustices. 


\section{Policy recommendations}

\section{Use music to inform and evaluate} citizen engagement initiatives. Music can provide vital insights into everyday forms of social and political action, and is a valuable source of data for context analyses that can be used to inform programming - from project baselines to the definition of areas of intervention.

2. Promote music beyond entertainment. Music can both shape and support development and civil society agencies' projects. Edutainment initiatives involving musicians can be enriched if messages in protest songs are used to influence project activities.

\section{Cultivate mutual learning on citizen} engagement strategies among singers, academics and civil society groups, on everyday expressions and citizen actions that tend to be dismissed as apolitical.

4. Address gender inequalities and misogyny. To tackle the under- and misrepresentation of women in political song, female songwriters and singers must be proactively invited to participate, and their participation enabled by dealing with gender-specific barriers. Training is needed for both female and male artists to help challenge stereotypes about women (and men) and foster more empowering narratives about women.

\section{Listen to audiences in all interventions} involving political song. Musicians are citizens who sing and express themselves from specific positions in society. When working with musicians it is important to also capture audiences' viewpoints to ensure that broader citizens' perspectives are taken into consideration.
Institute of Development Studies, Library Road, Brighton BN1 9RE, United Kingdom +44 (0)1273 606261 ids.ac.uk IDS is a charitable company limited by guarantee and registered in England. Charity Registration Number 306371. Charitable Company Number 877338.

\section{Further reading}

Manhiça, A. et al. (2020) Alternative Expressions of Citizen Voices: The Protest Song and Popular Engagements with the Mozambican State, IDS Working Paper 541, Brighton: Institute of Development Studies, DOI: 10.19088/IDS.2020.001

Manhiça, A.; Maivasse, C.; Gonçalves, E. and Taela, K. (2018) Expressões alternativas das vozes dos cidadãos: Música e comentário social em Moçambique, Maputo: Kaleidoscopio

- Research in Public Policy and Culture

Djive, A. et al. (2018) Fortalecendo a Legitimidade das Organizações da Sociedade Civil para o Empoderamento e Responsabilização Social: pesquisa-acção com organizações do movimento das mulheres em Moçambique, Relatório de Pesquisa, Maputo: Fórum Mulher
This IDS Policy Briefing was written by Kátia Taela, Euclides Gonçalves, Catija Maivasse and Anésio Manhiça from Kaleidoscopio and edited by Carol Smithyes, IDS. It was produced as part of the Action for Empowerment and Accountability (A4EA) research programme, funded with UK Aid from the UK government (Foreign, Commonwealth \& Development Office - FCDO)

The opinions expressed are those of the authors and do not necessarily reflect the views or policies of IDS or the UK government. (c) Institute of Development Studies 2021.

(i) This is an Open Access briefing distributed under the terms of the Creative Commons Attribution 4.0 International licence (CC BY), which permits unrestricted use, distribution, and reproduction in any medium, provided the original authors and source are credited and any modifications or adaptations are indicated.

ISSN 1479-974X

DOI: 10.19088/IDS.2021.020

\section{AAEA H

